OPEN ACCESS

Edited by:

Pedro Henrique Campello Torres,

University of São Paulo, Brazil

Reviewed by:

Bing Xue,

Institute of Applied Ecology

(CAS), China

Flávia Collaço,

University of São Paulo, Brazil

*Correspondence:

Robson da Silva Moreno robson.moreno@ufabc.edu.br; moreno.robson@gmail.com

Specialty section:

This article was submitted to

Urban Greening,

a section of the journal

Frontiers in Sustainable Cities

Received: 08 May 2021 Accepted: 20 September 2021

Published: 09 December 2021

Citation:

Moreno RS, Braga DRGC and Xavier LF (2021) Socio-Ecological Conflicts in a Global South Metropolis:

Opportunities and Threats of a Potential Greenway in the São Paulo Metropolitan Region. Front. Sustain. Cities 3:706857. doi: 10.3389/frsc.2021.706857

\section{Socio-Ecological Conflicts in a Global South Metropolis: Opportunities and Threats of a Potential Greenway in the São Paulo Metropolitan Region}

\author{
Robson da Silva Moreno ${ }^{1 *}$, Diego Rafael Galvão Cesar Braga ${ }^{1}$ and Luis Felipe Xavier ${ }^{2}$ \\ 1 Engineering, Modeling, and Applied Social Sciences Center, Federal University of ABC, São Bernardo do Campo, Brazil, \\ ${ }^{2}$ Architecture School of São Caetano do Sul University, São Caetano do Sul, Brazil
}

Greenways are a measure of environmental remediation within a broad framework aimed at promoting urban greening and adaptation to climate change. The typical characteristics of large urban agglomerations, including land use (such as commercial, industrial, and residential areas) with few public spaces and fragmented landscapes, make it difficult to apply these solutions to the urban fabric, forcing decision-makers and planners to act in informal settlements, highways, and industrial parks. One proposed area is an enclave with unused or underutilized lots, where fragments of the Atlantic Forest, parks, landfills, and rapidly expanding informal settlements can be found. This manuscript examines the socioeconomic and environmental processes that shaped this potential urban greenway between Santo André, Mauá, and Ribeirão Pires, which are part of the São Paulo Metropolitan Region (SPRM), the largest in South America. A survey was conducted based on municipal and regional plans, the environmental and urban laws of Brazil, and the socioeconomic history of this part of the SPRM. In addition, satellite images were used to analyze land use evolution through geotechnologies. Finally, we prepared land use recommendations, considering opportunities and threats, highlighting the possibilities of protection and expansion of the Atlantic Forest. To this end, we examined the literature on environmental urban planning and design, green infrastructure, and other concepts. This study intends to stimulate researchers, planners, and decision-makers regarding the urban greening process in the Global South. According to the recommendations, this stimulus would develop these concepts according to the real situation of the region, which would combine the protection of wild habitats and urban environmental amenities. However, this effort makes no sense if one of the defining Global South characteristics not addressed is social inequality. Therefore, we recommend that an effort be made to develop and incorporate processes from urban greening in slum upgrading.

Keywords: Urban Greenways, Global South, Atlantic Rainforest, Green infrastructures, Informal settlements, Dump sites, Landfills 


\section{INTRODUCTION}

Greenways have gained prominence among researchers, planners, and activists as an important element in urban greening that integrates design and ecology and makes a significant contribution to more livable cities (Frischenbruder and Pellegrino, 2006). In other words, they are an essential resource for addressing contemporary urban socio-environmental problems, many of which result from the twentieth-century concept of the city in a scenario of uncertainty in the face of climate change (Bonzi, 2017, p. 8; Chen et al., 2017; Moura, 2017). A greenway can be defined as a cluster of elements (green spaces) that enhance the fundamental connectivity between green urban areas and the remaining fragments of forest throughout a landscape (Frischenbruder and Pellegrino, 2006). This definition, which is adopted in this article, is broader than the similar term conceived by Little (1995), which only links green spaces or accessible areas that are established along natural corridors such as streams or empty lots in parallel to roads and railways. We understand the greenway as an element that is part of a framework for multiscale green infrastructure interventions (Chen et al., 2017). Tzoulas et al. (2007, p. 169) define it as:

(...) all-natural, semi-natural and artificial networks of multifunctional ecological systems within, around and between urban areas, at all spatial scales (...) [it] emphasizes the quality as well as quantity of urban and peri-urban green spaces.

Thus, multifunctional, and multiscale green infrastructure is based on spatial patterns of connectivity in a natural network (Ahern, 2007; Escobedo et al., 2019). Green urban spaces considerably enhance urban water management and air quality, reduce urban noise levels and human stress levels, create habitats available for urban wildlife, and enhance the performance and resilience of gray infrastructure (McPherson and Muchnick, 2005; Heynen et al., 2006; Tzoulas et al., 2007; Berland et al., 2017; Dong et al., 2017). These benefits can be applied to food production in urban areas (Jerome, 2017). However, the literature on urban greening processes, especially green infrastructure, rarely considers urban agriculture (Russo et al., 2017). This use of urban areas for food production could also meet a growing demand for vacant urban lots to be returned to citizens through a variety of urban agricultural practices (Thomaier et al., 2015; Liu et al., 2017).

In the region studied, the development of green infrastructure plans is still slow (Serra-Llobet and Hermida, 2017; Vásquez et al., 2019). In contrast, the Global South has the world's richest and most diverse ecosystem, including several biodiversity hotspots (Pauchard and Barbosa, 2013; Dobbs et al., 2019; Vásquez et al., 2019). Nagendra et al. (2018) argue that urbanization impacts in the Global South have adverse effects on rich ecosystems, mainly on water sources and soils. In some cases, the consequences can reach hundreds of thousands of kilometers (Nagendra et al., 2018).

To understand the relationship between rapid and precarious urbanization in the Global South, especially in Latin America, it is fundamental to consider that capitalist development has not occurred in this region in the same way as in major capitalist economies (Marini, 2015). The process that led $80 \%$ of the Latin American and the Caribbean population to live in urban areas resulted from the incorporation of their societies into the international system of the division of labor, helping to consolidate the industrialization that was taking place in the Global North (Pírez, 2013). The combination of a weak state, a reduced internal market, and rapid urbanization has resulted in large unplanned informal settlements in different places, giving us a small sample of how the reproduction of capital in the Global South is linked to the definition of territories for urban expansion, including the occupation of sites for the disposal of municipal solid waste (MSW), such as dump sites or landfills (Ogata, 1983; Rafael, 2006; Rodrigues and Zanirato, 2021).

The consolidation of an urban greening agenda has evolved since the 1970s. It requires and promotes reconciliation between the anthropic and the natural processes. Therefore, it is worth asking how we could induce the beginning of a human-nature relationship reconciliation process in a context where so many contemporary and historical socio-economic and political issues damage this relationship, such as the formal and informal pressures on the green areas still available in the largest metropolitan region of Brazil.

In an attempt to answer this question, this article analyzes a possible area for the establishment of an urban greenway located between three Brazilian municipalities, Santo André, Mauá, and Ribeirão Pires, in the southeastern part of the São Paulo Metropolitan Region (SPMR). This is one of the world's largest urban agglomerations, consisting of 39 municipalities (Figure 1), and the most urbanized and industrialized in Brazil. However, 2.1 million people of the SPMR live in precarious housing conditions, many in at-risk areas (Travassos et al., 2021). The three municipalities belong to the southeastern sub-region of the SPMR, known as the "Greater ABC." This region consolidated itself as an industrial region in the twentieth century, along the old railroad-the São Paulo Railway Company-from the seaport at Santos via São Paulo to Jundiaí, a coffee-growing region inaugurated in the 1860 s.

According to the São Paulo State Data Analysis Foundation (SEADE), in 2021, Santo Andrés population totaled 693,897 inhabitants, Maua's 463,338, and Ribeirão Pires's 119,339. Together, they include 6\% of the SPMR population, with $21,252,384$ residents (SEADE, 2021). It is worth noting that the population of these municipalities is not evenly distributed throughout the territory. More than half of the territory of Santo André has been declared an environmental protection area-a water-producing area-inhabited by $<5 \%$ of its population. In the urban area making up just over $40 \%$ of its territory, and on which $96 \%$ of its people are concentrated, the population density reaches 9,000 inhabitants per square kilometer. In this sub-region, where there are fragments of the Atlantic Forest and the old mining areas (some of them transformed into landfills), several precarious settlements have drastically increased in recent years due to the severe socio-political crisis taking place in Brazil.

Swyngedouw et al. (2002) argue that environments are specific historical results of socio-environmental processes. In their 

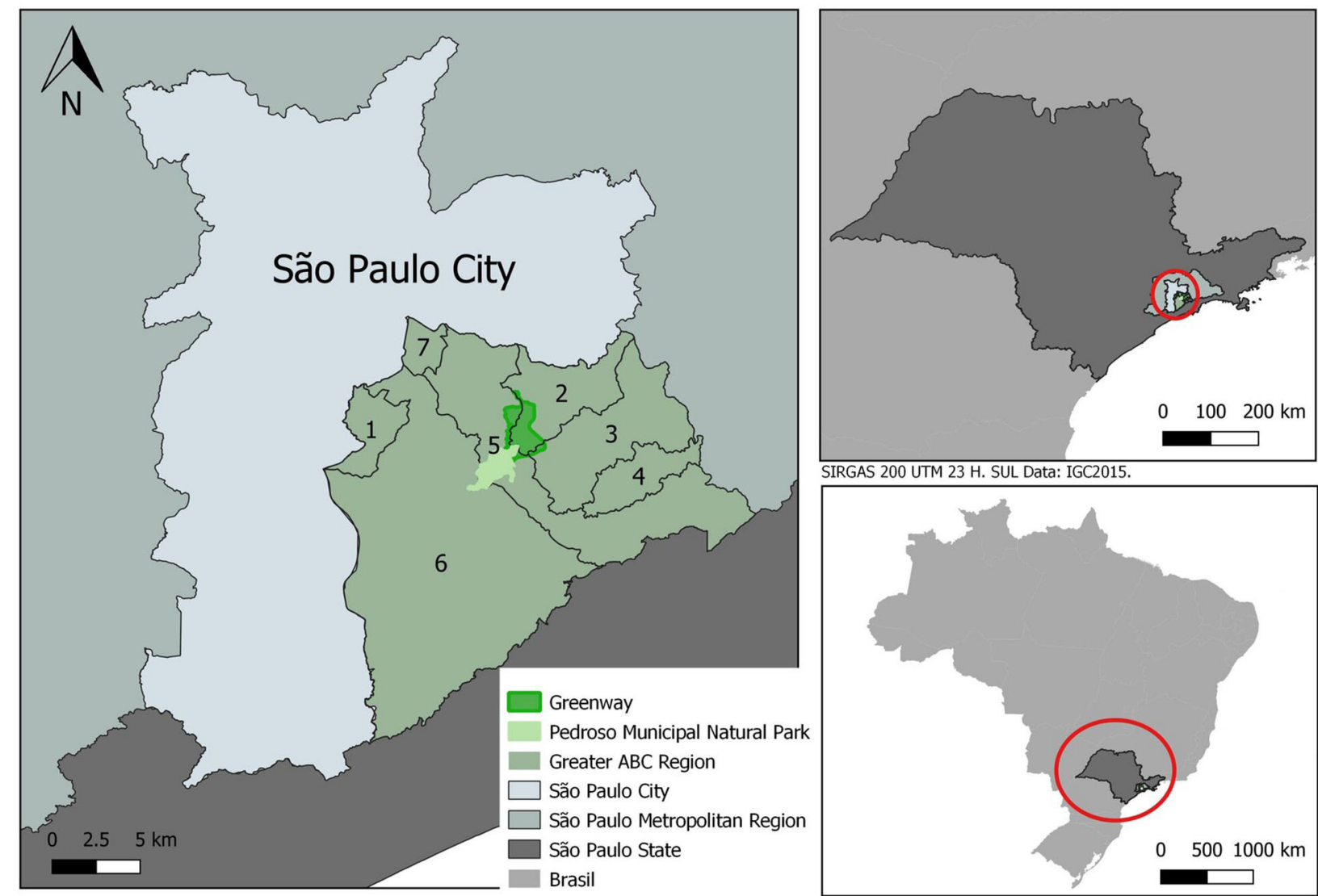

Greater ABC Region Cities: 1. Diadema; 2. Mauá; 3. Ribeirão Pires; 4. Rio Grande da Serra; 5. Santo André; 6. São Bernardo do Campo; 7. São Caetano do Sul.

FIGURE 1 | Location of the State of São Paulo, Metropolitan Region of São Paulo, Greater ABC, and the Greenway. This map was made by Beatriz Dunder (IEE-USP).

words, "the character of the physical and environmental changes and the resulting environmental conditions are not independent of the specific historical, social, political, or economic conditions" (Swyngedouw et al., 2002, p. 126). This statement explains what drove the area that we study, which we refer to as the Greenway, to take on its current characteristics. Based on the master plans of the three cities and the Greater ABC regional plans, we delimited an area starting from its northern end, which is a narrow strip of riparian forest on the banks of the Itrapoã Stream that forms the municipal boundary between Santo André and Mauá. We incorporated the Barão de Mauá residential complex, close to the limits of this riverine green space, because it was built on an old industrial dump site. We consider that the recovery of the soil quality of this residential complex is also part the integration process of the Greenway, for reasons that will be addressed in the later sections. The Pedroso Municipal Natural Park (PMNP) is located almost $6 \mathrm{~km}$ south of the northern part of the Greenway. To the east of the PMNP, we find the Lara Company Landfill in Mauá and some forest fragments. This strip comprises $\sim 1,207.79$ hectares (not including the PMNP area). This large greenway area has a history of different land uses, including mining, dump sites, landfills, housing, and industrial activities. We developed this review paper based on laws and municipal plans, especially the
Pedroso Natural Municipal Park Management Plan, an obligation under the National System of Conservation Units (NSCU). For this manuscript, we consulted the Climate Change Action Plan guidelines proposed by the Consortium of Greater ABC Municipalities. We selected green areas, among other types of areas, that had some level of connectivity for the delimitation of the Greenway situated no more than $20 \mathrm{~m}$ away from each other.

Land-use maps were constructed using the free software QGIS 3.16. The land-use classification was based on sattelite imagery from 2005 to 2020 obtained through the Orbview-3 satellite (provided by the U.S. Geological Survey Earth Resources Observation and Science [EROS] Center). From these images, a semi-automatic classification was performed with the assistance of the SCP program for QGIS based on a previous collection of samples carried out by photo interpretation, corrections, and on-site verification.

The first part of this paper presents a brief description of the macro institutional framework and of the Climate Change Action Plans of the Greater ABC Consortium, which proposes guidelines and actions that we developed in this work, specifically in the proposal for the buffer zone in the PMNP Management Plan.

The next section discusses the Greenway area and its biotic, physiographic, and socio-economic characteristics. In the second 
half of this section, we make a brief diagnosis of the natural and man-made elements of the cities and the region that compose the Greenway.

\section{ASSESSMENT OF OPTIONS AND IMPLICATIONS OF GUIDELINES}

\section{Institutional Framework}

Analyzing the SPMR environmental plans and zoning, it is noted that the Greenway area in southwestern of the "São Paulo Green Belt Biosphere Reserve". UNESCO recognized the Green Belt of São Paulo as a Biosphere in 1994, by UNESCO's "Man and Biosphere Program". UNESCO established the Biosphere Reserves sites to host a network of areas on the globe with relevant environmental value to humanity (UNESCO, 2021). The São Paulo City Green Belt Biosphere Reserve is over 600,000 hectares of forests and other Atlantic Forest ecosystems (Ribeiro, 2015).

The first element of analysis is the PMNP, the largest conservation unit in the Greater $\mathrm{ABC}$, and its management plan (SEMASA, 2016). The National System of Conservation Units determines the mandatory elaboration of management plans for all Conservation Units, and buffer zones are among the many actions to be defined in these documents. They correspond to "the surroundings of a conservation unit, where human activities are subject to specific rules and restrictions, to minimize the negative impacts on the unit" (Brasil, 2000, p. 2). Therefore, their function is to protect the conservation units from the possible impacts of human activities, or at the very least to mitigate them, preventing their fragmentation and edge effects. This strategic function is indicated by Dramstad et al. (1996), who emphasized the importance of buffer zones to minimize impacts on protected areas according to landscape ecology. Thus, the PMNP management plan establishes two categories of buffer zones: class 1, delimited around PMNP, but restricted to the municipality of Santo André; and class 2, which goes through and beyond the city, being defined in collaboration with neighboring municipalities while taking into consideration the specific state law focused on the protection of water sources: the watershed protection law of the Billings Reservoir Hydrographic Basin (São Paulo, 2009), the largest in the São Paulo Metropolitan Region.

The second element that supports our study is the Greater ABC Consortium's Action Plan to Combat Climate Change (CIGABC and ICLEI, 2016). From this plan, we highlight, from among the 52 potentialities, two items for environmental and territorial planning: (1) the "Mosaic," which allows for a mosaic of regional conservation areas in the watershed of the Billings Reservoir, and (2) ecological corridors interconnecting the borders of parks, buffer zones, and green spaces. However, our focus is on the buffer zones, especially those suggested by the PMNP management plan. This management plan delimits the transition sites to the north as buffer zones, creating a corridor that circumvents areas of high population density. The mosaics need to be investigated, especially concerning the impacts of the Rodoanel Highway (Ferreira, 2012; Brito, 2014). This highway bypasses the SPMR and reaches areas of interest for environmental preservation, which could serve as possible connections with other conservation units and protected areas. However, discussion of this issue lies outside the scope of this study.

The following is a brief description of the region's native vegetation and its natural and man-made characteristics.

\section{Atlantic Rainforest and Dense Montane Rainforest}

The urban areas presented in this study are located in a forest formation classified as dense montane rainforest. This formation has three main characteristics: (1) the high density of vegetal organisms per square meter; (2) the fact that it can be found at elevations between 500 and $1,500 \mathrm{~m}$; and (3) a high number of rainy days, from 305 to 365 days with some level of rain, and high mean temperatures $\left(25^{\circ} \mathrm{C}\right)$ throughout the year. Other characteristics include its phanerophyte vegetation cover with a mean canopy size of $20 \mathrm{~m}$, and the soil, which plays an important role in determining the size of the vegetation (IBGE, 2012). This particular forest formation is inserted in the Atlantic Forest phytogeographic region. Being the second largest forest in South America (Muylaert et al., 2018), the Atlantic Forest is crucial for the conservation of biodiversity and for the preservation of human wellness both locally and globally, as shown by Marques et al. (2021).

Anthropic expansion and attendant habitat fragmentation have driven the Atlantic Forest and its native biodiversity to a critical level of danger. The weak environmental governance and dismantling of environmental policies by the Brazilian government reinforce the land-cover change, which is the main source of damage to the biome (Abessa et al., 2019). The Atlantic Forest has been degraded since the discovery of Brazil in the sixteenth century. Historically, the Brazilian economy has been based on the deforestation of this biome: the extraction of brazilwood (Paubrasilia echinata) from the coast of the country or precious metals from the mountains, sugarcane, and later coffee farming cycles under the plantation system, and, since the second half of the last century, rapid urban sprawl and increases in population (Lira et al., 2021). This biome houses many of the most densely populated state capitals and cities and two of Brazil's main megalopoli, São Paulo and Rio de Janeiro. Together, they are inhabited by more than 50 million people, who directly depend on the ecosystem services of the forests (Carlucci et al., 2021; Pires et al., 2021).

\section{Parks, Streams, and Geomorphology in the Proposed Greenway Through Santo André, Mauá, and Ribeirão Pires}

The Atlantic Forest covers almost half of the Santo André and Ribeirão Pires land area, a high percentage of their territories than in other cities in the state of São Paulo. Data from the Forest Information System of the São Paulo State (São Paulo, 2020) show that, in the case of Mauá, the area we defined as part of the Greenway area holds around $65 \%$ of its forest 


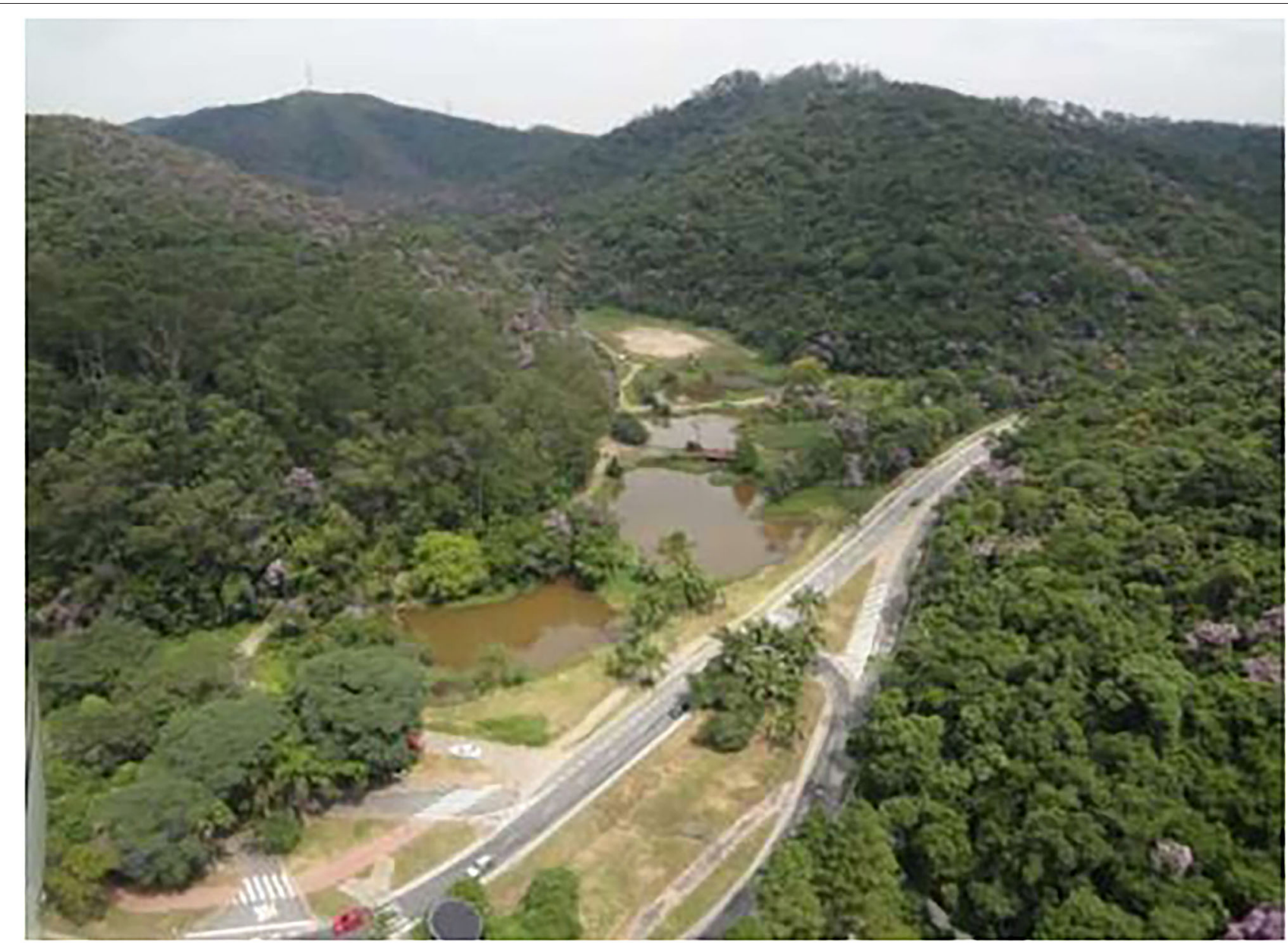

FIGURE 2 | View of the Pedroso Municipal Natural Park (PMNP), (SEMASA, 2016).

cover. The city of Santo André, whose territory is almost three times as large as that of Mauá (18,100 vs. 6,700 hectares), has a higher percentage of Atlantic Forest still standing (35.78\%), but the largest concentration of forests is to the south, away from the Greenway.

Ribeirão Pires, with a minor fraction of its territory in the Greenway (only 63.1 hectares), has an area of 10,700 hectares. Mauá contributes to the Greenway with 824.6 hectares, almost the totality of this forested land located in the industrial district (Mauá, 2007, 2016). Santo André has 318.2 hectares in the Greenway. Although forested areas are under considerable pressure from urban sprawl, they still maintain considerable biodiversity. For example, a survey of birds shows more than 300 species close to the Santo André landfill, some of which are at risk of extinction (SEMASA, 2021). It is worth mentioning that the three municipalities have a significant part of their territories in the watershed protection area-Ribeirão Pires has 100\% of its territory in that area, with Santo André and Mauá having 55 and 19\%, respectively (Figure 1). The overlap of the Greenway territory with watershed protected areas (the Billings Reservoir Basin) makes up only a small part of its southern area. To the west, the PMNP borders Santo André and Ribeirão Pires, where there are some fragments of the native forest and some exotic species reforestation (silviculture), according to the Forest Inventory of the State of São Paulo (São Paulo, 2020).

The main element to be connected to the Greenway, Pedroso Municipal Natural Park (PMNP), is an 812-hectare park created in 1944 to safeguard a fragment of the native forest and protect the watershed for the water provision for the city of Santo André (Figure 2; Freitas, 2011; SEMASA, 2016). As the PMNP is close to the neighboring municipalities, its buffer zone goes beyond Santo Andrés municipal limits. This conservation unit serves a variety of human uses, including a leisure area, for the population of neighboring regions, many of which are precarious settlements. There is also a sanctuary of Umbanda, an Afro-Brazilian religion, which was officially established in the PMNP with a concession by the Santo André municipal government in 1985. It occupies an area equivalent to $7.42 \%$ of the total area of the park (SEMASA, 2016). Within the PMNP perimeter, there are still other structures with different uses: a Catholic chapel, "Santa Cruz dos Carvoeiros"; a Japanese garden; a water pumping station for provision purposes; and the municipal vivarium. 
This conservation unit is under significant anthropic pressure because it is close to densely populated areas, especially on its northern limits (Freitas, 2011), and suffers from the impacts of the Rodoanel Highway, built in the early 2000s (Ferreira, 2012).

There are two parks within the Greenway's limits. The first is Guaraciaba Park, also in Santo André, which is smaller than PMNP, with 52 hectares. Guaraciaba Park is a micro drainage watershed with remnants of the Atlantic Forest inside (SEMASA, 2004). The lake is the result of a sand extraction operation that took place between the end of the 1950s and the beginning of the 1980s (Figure 3). This lake has only 7.7 hectares with satisfactory ecological and sanitary quality (Mucci et al., 2004; SEMASA, 2004). Momm-Schult et al. (2014) identified a potential green corridor that could connect this park to PMNP to its south, as well as the already known environmental benefits that its creation could secure. Finally, in the proposed Greenway area, there is a small park to be considered, Marek Park, north of the Santo André landfill, with an area of 2.93 hectares.

Regarding the geomorphological domain of the region, the environmental impact study evaluated the possibility of expanding the Santo André landfill (SEMASA, 2008) into an area of low-lying hills with closed valleys (Poletto, 2006; SEMASA, 2008). The water springs in this region form the tributary streams of the Tamanduateí River, the main river in the southeastern region of the Greater ABC (Santo André, 2004; SEMASA, 2004).

\section{Uses, Impacts, and Threats}

It is essential to highlight that the three cities (Santo André, Mauá, and Ribeirão Pires) are part of the axis that promoted urban growth in the cities of the SPMR-the Santos-Jundiai Railway; in 1946, the São Paulo Railway Company was nationalized and became the Estrada de Ferro Santos-Jundiaí. The railroad was responsible for the first stage of industrialization in the Greater $\mathrm{ABC}$ between the early twentieth century and the 1950s (Ribeiro, 2008). The second stage was promoted by the automobile industry, with the construction of the Anchieta Highway in 1947 between São Paulo and the Port of Santos. This whole region had a high growth rate as a result of the expansion of the industrial sector (albeit based on low wages), especially in the 1950s. According to IBGE, between the 1960s and the 1980 s, the region had a growth rate of $227.70 \%$, which was higher than those of the SPMR (162.70\%), São Paulo (95.5\%), and Brazil as a whole (69.8\%). Due to the debt crisis of 1973, the Greater $\mathrm{ABC}$ region underwent a localized process of deindustrialization, which substantially decreased the previously presented growth rates, reaching $42.50 \%$ between the 1980 s and the 2000 s (IBGE, 2021), closer to the growth rate of the SPMR and that of Brazil as a whole. The departure of industries from the region and the change in the capital accumulation matrix after the mid1970s generated a "tax war," impacting economic activities, the production and distribution of wealth, and the availability of jobs, altering the levels of income, building infrastructure, and implementation of public policies (Ribeiro, 2008).

Although the Greater $\mathrm{ABC}$ region has undergone economic restructuring (through the generation of wealth driven by industrial production for the service sector), it accounts for more than $10 \%$ of the gross domestic product of the SPMR and almost
$6 \%$ of that of the state of São Paulo (EMPLASA, 2017). This urbanization process generated a considerable contrast: On the one hand, we have urban areas concentrated to the north, in the municipality of Santo André, where most of the population lives and where most of the services and industries are still located; on the other hand, in the south of this region, we find a loosely populated area where the Billings Dam Watershed lies (CIGABC and UFABC, 2016). The Billings Dam Watershed is also responsible for part of the drinking water supply of the cities in the region. As a result, it now has its own hydrographic basin, which occupies $56 \%$ of this sub-region, protected by a state law promulgated in the 1970s, in the same region where we find the Sertãozinho Industrial District (belonging to the municipality of Mauá), created in 1975, 1,160 hectares in area (Mauá, 2007) and access to the "Rodoanel." This highway, which has been under construction since the 1990s, bypassed the SPMR (Ferreira, 2012).

To understand the current status of the studied area, it is important to examine the history of its land use. Specific mining sites were used to configure places for other services. Observing the aerial photos of 1990, the Guaraciaba Park Plan (SEMASA, 2004), and the Santo André landfill study (SEMASA, 2008), we found two sand extraction sites that were active between the 1950s and the 1990s. The first and smallest resulted in Lake Guaraciaba. The second site became the current Lara Company Landfill in Mauá. It is worth mentioning that there is a lack of information about mining activities in the SPMR until the end of the 1970s (Poletto, 2006). From the surveys carried out, we estimated that in the same period in which mining activities were taking place, the final disposal of MSW was already underway in the dump site on Espírito Santo Street (Rafael, 2006; SEMASA, 2008).

\section{Dump Sites and Landfills}

The history of the final disposal of MSW in the Greater ABC can be divided into two parts. The first period was between the 1950s and the 1980s, with the registration of dump sites in Santo André and Mauá (Rafael, 2006; CETESB, 2013; Okamura et al., 2015). The second period, with the disposal of MSW in landfills in Santo André and Mauá, began in the 1980s. An emblematic case is the industrial dump site located on a vacant lot in Mauá on the banks of the Itrapoã Stream, which establishes the limits between the municipalities of Mauá and Santo André. The COFAP factory (Companhia Fabricadora de Peças) used approximately 16 hectares of this area to deposit industrial solid waste, predominantly foundry sand (CETESB, 2013; Okamura et al., 2015). The lack of information about its history is a striking feature of this dump site. There are no exact data on the operation dates or on the characterization and volume of the solid waste disposed of. Reports and interviews with company employees stated that the operation took place $\sim 40$ years ago (Okamura et al., 2015). The only thing that is known for certain is that COFAP bought this lot in 1974 and sold it to the housing cooperative "Cooperativa Habitacional Nosso Teto” in 1995 (Matsuura, 2006). The Barão de Mauá residential condominium was built in this area where industrial residues were disposed: a group of eight-story buildings, four apartments 


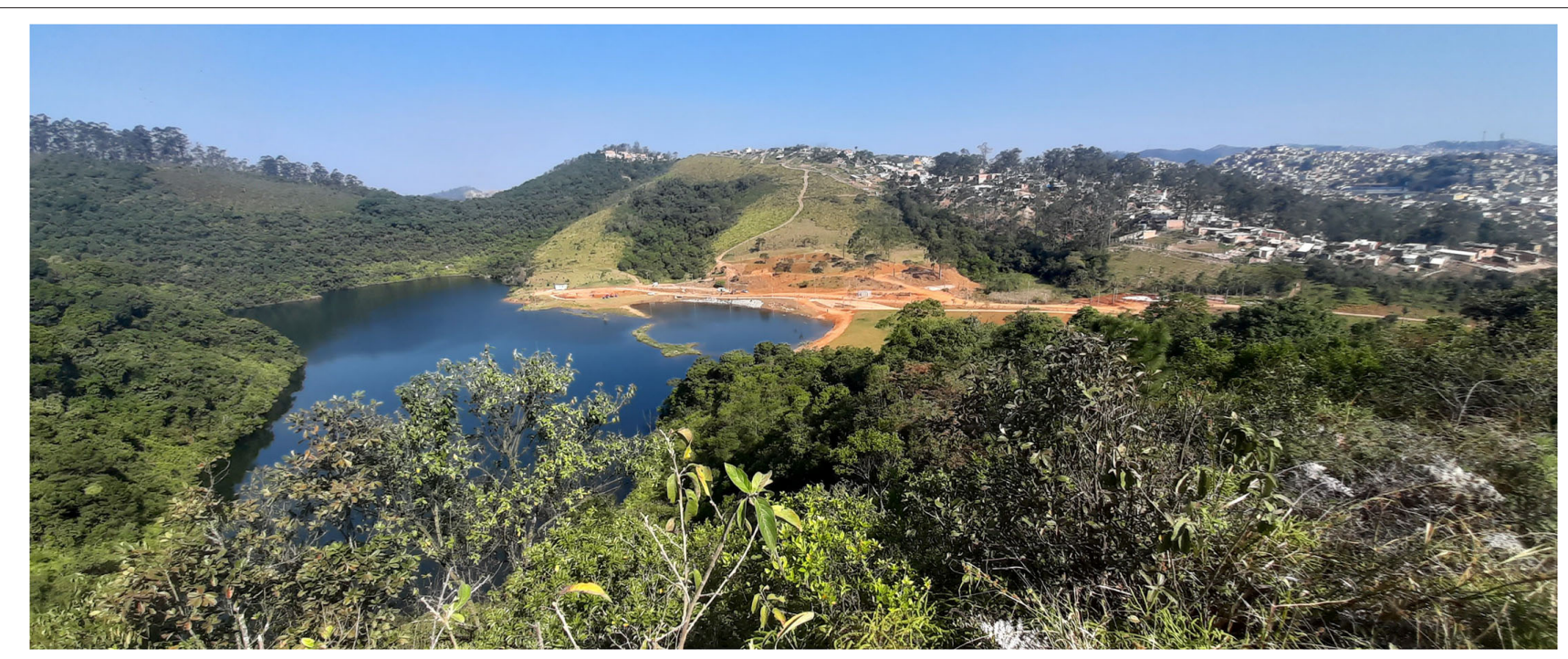

FIGURE 3 | View of the Guaraciaba Park Lagoon and its southern slope, limited by the informal settlement Vista Alegre/Sítio Cassaquera and eucalyptus reforestation areas. The work carried out by the Santo André Green Space Department to reopen this park is shown. Source: Author's photo, taken on May 2nd, 2021.

per floor, totaling 59 buildings distributed over nine blocks, where about 7,500 people live. The project prescribed 72 blocks in total. Part of the area is contaminated by 44 toxic substances, including benzene, chlorobenzene, trimethyl benzene, decane, and other organic and inorganic volatile compounds. This contamination was discovered through an accident in April 2000: Workers who maintained a lower reservoir of drinking water in one of the buildings were hit by an explosion that resulted in one death and two injuries (Matsuura, 2006). The legal actions against the liable company required the adoption of remediation actions, such as the identification and characterization of contaminants and the remediation of the soil and groundwater in the condominium area (Figure 4; CETESB, 2013). In 2015, the environmental recovery required by the São Paulo State environmental agency (CETESB) began, according to the Justice decision.

In his master's dissertation at the Polytechnic School of the University of São Paulo (USP), Luis Fernando Armidoro Rafael identified several sites of irregular waste disposal in the city of Santo André. The dump site on Espírito Santo Street operated from the late 1950s to 1981 and occupied 2.8 hectares. In this area, $\sim 108,000 \mathrm{~m}^{3}$ of waste was deposited from households, general cleaning, industrial, and infectious refuse (Rafael, 2006).

For the dump site on Espírito Santo Street, there was a similar change in land use after the MSW disposal operation was terminated to housing. However, as is usual, this kind of precarious settlement occupies areas with environmental risks (Rodrigues and Zanirato, 2021). These factors compromise the geotechnical stability at the site, which has a slope above $15 \%$. By the beginning of 2013, 820 houses had been demolished and their families moved to apartments built in Santo André (Marguti, 2013).

Technological development, associated with environmental control and engineering design standards, has made this landfill a safe option. However, this option for the disposal of solid waste generates externalities and, after its closure, control measures must be taken continuously for many years (Barros, 2017, p. 262). The Lara Company Landfill (Mauá) originated from an old sand extraction area in the early 1990s. It receives MSW generated by all the municipalities of the Greater ABC (except for Santo André), as well as MSW from three medium-and smallsized towns in the São Paulo state (CETESB, 2018). In the current phase, the Lara Landfill covers an area of 75 hectares, near to Billings Watershed Protected Area (CIGABC and FESPSP, 2016; CPEA, 2019). In 2019, CETESB approved an environmental license for construction of a waste-to-energy plant (CPEA, 2019) that will occupy 7.2 hectares within the Lara Treatment Center and will be built near the landfill. It was approved despite opposition from social movements (COMUGESAN, 2020) and particularly waste pickers' organizations (São Paulo, 2019). The Santo André Waste Treatment Plant began operations in the early 1980s with a composting plant between 1982 and 1997. The landfill began in 1986 and lies north of Guaraciaba Park (SEMASA, 2008). Currently, landfill management is preparing a new stage, which is under the licensing process with CETESB, with an additional 3.9 hectares of the area (from a total of 32.8 hectares) providing another 5 years of service life. Both landfills are approximately five kilometers apart and are well-evaluated by CETESB (Melo, 2020).

\section{Concepts and Strategies for the Urban Greenway and Green Infrastructure}

As a result of the heterogeneous character of the land use in the area studied in this article, we suggest the adoption of the four planning strategies proposed by Ahern (2007): protective and preventive preservation measures; offensive, corrective, or restorative actions; defensive measures, implementing actions to defend the elements of the landscape that are under pressure; 


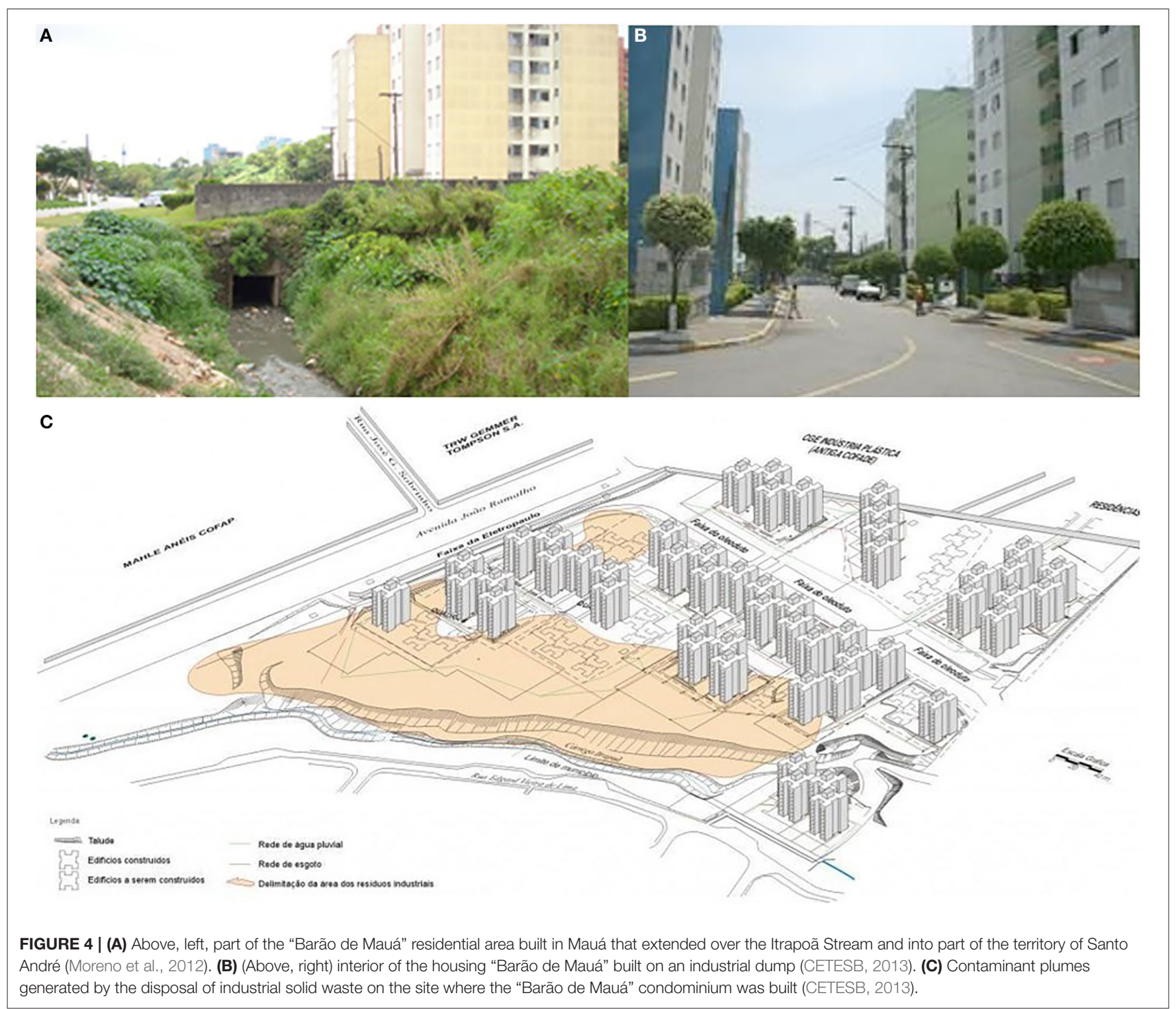

and opportunistic, recognizing the potential of non-contributing aspects of the landscape. The main element that guides this study is the buffer zone established by the PMNP management plan. Thus, we assume that defensive strategies are evident. We apply a multi-scaled approach based on hierarchy theory, which addresses the structure and behavior of systems that function simultaneously at multiple scales (Ahern, 2007).

Escobedo et al. (2019) argue that interdisciplinary knowledge of urban ecosystems has evolved in recent decades, adopting a series of metaphors, such as green infrastructure and naturebased solutions, among others. We have adopted the concept of green infrastructure, as it is strongly linked to spatial standards (Ahern, 2007; Escobedo et al., 2019), since territorial planning is the premise of this article. It is also worth mentioning that "nature-based solution" has arisen as a new concept to cover the applications used to solve a series of urban and sociopolitical environmental problems (Dorst et al., 2019; Escobedo et al., 2019). Thus, it is worth noting that the concept of green infrastructure proposes planning and environmental design practices that incorporate components that articulate at different scales, ranging from urban lots to city-scale interventions (Tzoulas et al., 2007; Escobedo et al., 2019).

Therefore, for the guidelines summarized below, it is necessary to consider some aspects of the different scales that green infrastructure addresses. Yu and Padua (2006) developed a similar concept, the ecological infrastructure, according to which ecological services are delivered on three scales: large, medium, and small. Bonzi (2017) associates these scales in the following way: the macro scale deals with "green belts," types of land units that often shape urban areas and which, in this work, are 


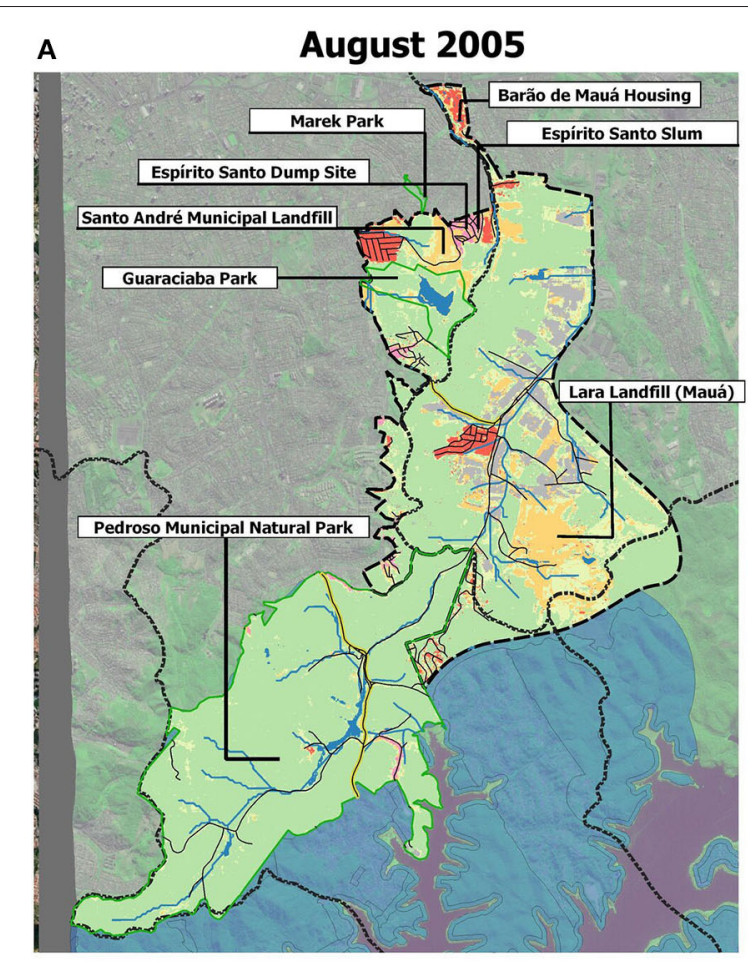

SIRGAS 2000 UTM ZONE $23 \mathrm{H}$. SUL Data: IGC 2015; CEM 2020.

Image: Orbview 3 - 08-2005 Landsat 8 - 09-2020 U.S Geological SURVEY; INPE Software: SCP for QGIS
B September 2020

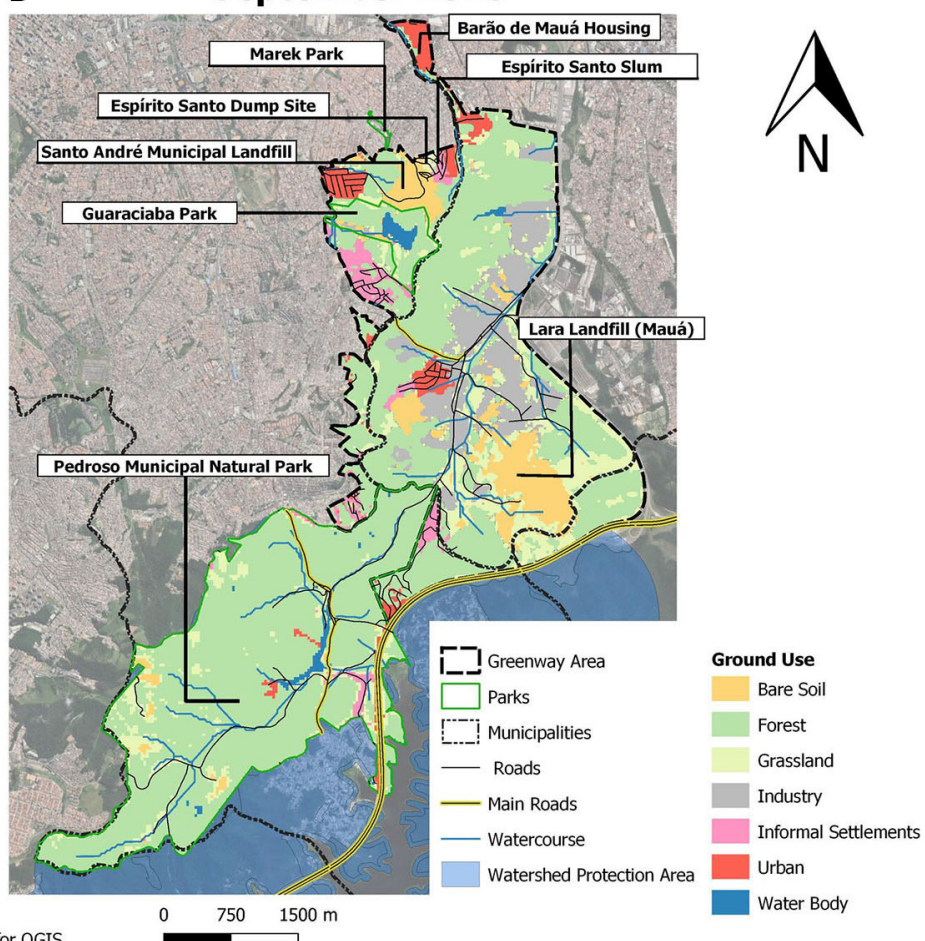

FIGURE 5 | (A) Greenway 2005 land use map (top left). (B) Greenway 2020 land use map (top right). The land use maps were made using free software from QGIS geotechnologies based on Landsat images from 2005 to 2020 from the Orbview-3 satellite (provided by the US Geological Survey Earth Resources Observation and Science -EROS- Canter). These maps were made by Beatriz Dunder (IEE-USP).

associated with watershed protected areas, large rural or periurban areas of agricultural production, and with conservation units (Brasil, 2000); the mesoscale, associated with types of green infrastructure such as street trees, riparian vegetation, constructed wetlands, stormwater ponds, and wildlife crossings; and the microscale, associated with bioswales, rain gardens, cisterns, and green roofs (Bonzi, 2017).

In this article, the Greenway is associated with the macroscale, which is, in the definition of $\mathrm{Yu}$ and Padua (2006), the level of the units that shape the limits of cities. For these authors, this pattern is linked to ecological networks, heritage corridors, and recreational corridors. These elements must be planned to take into consideration their own protection, but measures must be adopted to expand urban greening in the industrial district and residential neighborhoods in the Greenway. These structural elements are addressed in the following sections.

\section{RECOMMENDATIONS}

Keeping in mind the precepts mentioned above, we propose guidelines based on the land use map presented below.

Analyzing the land use map (Figure 5) and data obtained from previously mentioned reports (Table 1), we notice elements that reinforce the recommendation that this area becomes a greenway. The forest had the highest percentage of land use types (39\%). If we add the park areas, forest, and grassland (5.8\%), we have almost half (49.2\%) of the greenway area covered by green spaces. The second-highest variety in land use is found in the industrial district (23.4\%), and despite their impacts, landfills and dump sites make up just $12.9 \%$. Residential districts served by urban infrastructure accounted for $7 \%$ and precarious (informal) settlements at $6 \%$. The largest part of the forested land in the Greenway is in Mauá in the industrial district area.

Based on the different land uses identified in land use Map 1 , we propose guidelines that follow the principles put forth by Yu and Padua (2006), Ahern (2007), and Bonzi (2017), as shown in Table 1.

For each type of urban element identified in Table 1, we provide detailed recommendations regarding its treatment.

- Dump sites and landfills

Although landfills are the best option for MSW disposal, they also generate impacts on the land and need adequate treatment before, during, and after their operating life. Management is necessary after the closure. Thus, we put forward recommendations for both types of sites in these general guidelines; more specific approaches to each site will be detailed in future works. Regarding the COFAP dump site, it is necessary to investigate the adequacy of the use of this site as a housing area. In the absence of 
TABLE 1 | Land use and possible guidelines to be adopted to consolidate the proposed urban greenway.

\begin{tabular}{|c|c|c|c|}
\hline Urban elements & $\begin{array}{c}\text { Size } \\
\text { (hectares) }\end{array}$ & $\%$ & Guidelines \\
\hline Residential neighborhoods & 84.08 & 6.9 & $\begin{array}{l}\text { Small and medium-scale } \\
\text { green infrastructure }\end{array}$ \\
\hline Industrial districts & 284.97 & 23.4 & $\begin{array}{l}\text { Small and medium-scale } \\
\text { green infrastructure }\end{array}$ \\
\hline Informal settlements & 61.97 & 5.1 & $\begin{array}{l}\text { Small and medium-scale } \\
\text { edible green infrastructure/ } \\
\text { "green slum upgrading" }\end{array}$ \\
\hline Landfills and dump sites & 157.37 & 12.9 & $\begin{array}{l}\text { Medium and large-scale } \\
\text { green infrastructure } \\
\text { (phytoremediation) }\end{array}$ \\
\hline Lakes & 16.29 & 1.3 & $\begin{array}{l}\text { Medium-scale green } \\
\text { infrastructure }\end{array}$ \\
\hline Roads/highways & 1.86 & 0.2 & $\begin{array}{l}\text { Medium-scale green } \\
\text { infrastructure }\end{array}$ \\
\hline Bare soils & 10.34 & 0.9 & $\begin{array}{l}\text { Small and medium-scale } \\
\text { green infrastructure }\end{array}$ \\
\hline $\begin{array}{l}\text { Atlantic forest (Native and exotic } \\
\text { species) }\end{array}$ & 474.40 & 39.0 & Protection/reforestation \\
\hline Grassland & 70.62 & 5.8 & Agroforestry/reforestation \\
\hline Parks (not including PMNP) & 54.10 & 4.4 & $\begin{array}{l}\text { Medium and large-scale } \\
\text { green infrastructure }\end{array}$ \\
\hline Total & $1,207.79$ & 100.00 & \\
\hline
\end{tabular}

Information about urban land use was obtained through a comparative land use survey between 2005 and 2020 carried out by Beatriz Dunder (Figures 5A,B) and data provided by the mentioned plans and reports (e.g., Santo André Landfill Environmental Impacts Study, Lara Waste-to-energy Environmental Impacts Study, PMNP Management Plan).

data confirming the complete decontamination of this site, it is not possible to take a final position regarding its use. Phytoremediation is recommended for the Espírito Santo Dump. Although phytoremediation techniques are known as alternative or complementary methods to conventional methods, Nagendran et al. (2006) and Kirpichtchikova (2009) emphasize its versatility in application to different types of pollutants, combined with a low-cost treatment. Thus, it offers solutions to many related environmental problems, demonstrating its usefulness in waste management (Nagendran et al., 2006). For example, some studies of dumps and landfill treatment through phytoremediation have shown interesting results (Nagendran et al., 2006; Barros, 2017). The objective of these actions is to return this site to citizens as a public park, promoting the expansion of green coverage in Greenway. Therefore, it is necessary to consider the restoration of closed landfills. Santo Andrés landfill should cease operations within 5 years, and it is urgent to consider the project for its closure and measures to deal with it afterwards. In this case study, some research results demonstrate the potential for transforming closed landfills in parks (Do et al., 2014; Barros, 2017; Klenosky et al., 2017). The Lara Landfill will have a longer service life. Its area is larger than that of the Santo André landfill. It is also close to the limit of the Billings
Basin. Part of its expansion area is in the environmental protection zone. Therefore, it is essential to prepare a macro zoning plan that follows the guidelines to be defined for dump sites and landfills to guarantee the connectivity of the PMNP area with other protection areas further south.

- Highways and roads

The literature points to the possibility of implanting green corridors on their sides (Little, 1995; Ahern, 2007), which is a good way to utilize these open and unused spaces. However, it is necessary to develop studies for the implementation of wildlife crossing infrastructure (Ahern, 2007; Bonzi, 2017), especially in areas bordering the PMNP, the major conservation unit of this region. The Guaraciaba and Pedroso Parks' internal roads and Papa João XXIII Avenue should be studied as possible venues for the planting of street trees and the implementation of wildlife crossings, as well as other small-and intermediate-scale green infrastructure.

- Residential neighborhoods and industrial districts

For these areas, it is necessary to develop guidelines for the implementation of small-and intermediate-scale green infrastructure components (Yu and Padua, 2006; Ahern, 2007; Bonzi, 2017). Examples include green roofs and walls, cisterns, bioswales (small scale), street trees, riparian vegetation, ponds, and constructed wetlands (intermediate scale).

- Informal settlements

There are four slums in the Greenway: two within the city limits of Santo André, one within Mauás limits, and the Vista Alegre/Sítio Cassaquera, the largest, which occupies areas between both cities. We do not address the slums to the south of the urban area of Santo André, to the north of the PMNP (Jardim Santo André), or to the south of the PMNP (watershed area), as these places lie outside the limits of the Greenway and thus will be evaluated later in our research. The resumption of slum urbanization must be a priority to afford the residents of risk areas, currently subject to floods and landslides, a safer and more dignified life. A survey performed in 2006 by the Housing Department of Santo André (Santo André, 2006) found that half of Vista Alegre slum residents lived in risk areas. Therefore, it is necessary to reallocate these families from hazardous places to new housing projects. However, it is necessary to update the information on precarious settlements collected through surveys from the housing departments of Mauá and Santo André. All available information is now outdated, at a time when the territorial expansion of informal settlements is notorious. The discussion of the expansion of the area of these settlements is based on satellite imagery obtained from Landsat 5 in 2020.

- Parks

We recommend actions to promote forest restoration with native species and assess and control the quality of the edges of forest fragments, as well as the control of invasive exotic species. This means supplying green infrastructure to the buffer zones, especially in the green corridor and bordering areas. This is to be implemented in existing and future parks and in the buffer zones of the PMNP. 


\section{DISCUSSIONS}

This manuscript sought to provide a review of urban greenway literature and outline general guidelines for the implementation of a heterogeneous greenway, which requires coordination between multiple neighboring municipalities. However, this proposal comes up against a decrease in public investments (performed to reduce the role of the State), a deep socioeconomic crisis combined with a political crisis, and the erosion of fragile liberal democracies, especially in countries on the periphery of global capitalism such as Brazil (Dowbor, 2018). Because of this situation, this study indicates possible paths in the opposite direction of this trend, strengthening and improving public institutions to face the socio-environmental challenges posed. Momm-Schult et al. (2014), when analyzing Guaraciaba Park, denounced the disarticulation of the public sector, which has kept this park unusable by the population since its opening in 1992. This strengthening involves the resumption of medium-and long-term planning outlined by the Greater $\mathrm{ABC}$ Consortium, including an action plan to tackle climate change. It is necessary to implement the guidelines and actions established in the Greater ABC Action Plan in accordance with the strategies of Ahern (2007).

Another issue to be faced is the conservatism of institutions, both public and private, when dealing with emerging concepts in environmental planning and design, such as green infrastructure. We note that the structure of municipal administrations still depends upon twentieth-century engineering (Moura, 2017), which involves rules and procedures that must be revised. In addition, multidisciplinary teams of planners and engineers from different sectors of the local government are required to deal with green infrastructure plans and projects. However, given the complexity and extended timescale of green infrastructure, partnerships with researchers, NGOs, and social movements are essential. The participation of actors from different sectors of civil society is necessary because of the reduced predictability of results and the non-linear nature of green infrastructure projects (Ahern, 2013).

Paradigm changes are also necessary to manage the areas intended for preservation and restoration of the Atlantic Forest in this region. As most of it is found in the industrial district, it is necessary for this management to act on the borders of forested lots. In order for this to occur, it is important to promote urban greening in constructed areas such as industrial buildings and parking lots. The relevance and opportunities for improvement in the Greater $\mathrm{ABC}$ urban framework triggered by the preservation of the Atlantic Forest areas cannot be underestimated, as well as their threats, which we seek to summarize in Table 2.

This study focuses on Atlantic Forest coverage, but it does not ignore exotic species coverage, even though this represents a smaller fraction of the green areas we surveyed. The most widespread exotic species is eucalyptus (Corymbia citriodora). A praiseworthy example of forest management is an old farm, "Fazenda Tangará" (Tangará Farm), where a paint factory is located. There, we can find sites with coverage of native vegetation and areas covered with eucalyptus, that total 66.8 hectares. Forest management was carried out in this area in 2007, involving the replacement of exotic species with native ones in an area that totaled 38.42 hectares (FIESP, 2018). On the other hand, there is an undesirable example of forest treatment in private lots in Mauá involving the felling of 11.8 hectares of forest for the construction of a logistical warehouse at Maua's industrial hub (Martinez, 2018). Such findings are important because, in the preliminary survey carried out with land use maps (Figure 5 and Table 1), we observed that the industrial districts of Maua had the largest expansion in the period between 2005 and 2020 (a growth of 82.5\%). On the other hand, there are few public spaces in the Greenway. Parks in areas along municipal boundaries are unexplored possibilities. Santo André had unfulfilled plans for a 4.85 -hectares park on the banks of the Itrapoã (SEMASA, 2011). Our research found that if we used the Maua side, with public and private lots, this area would increase to 15 hectares, including the old COFAP dump site.

We also observed a strong anthropic pressure on 318 hectares of the Santo Andrés portion of the Greenway. This is less than the observed expansion of the industrial district of Mauá. The areas with precarious settlements were concentrated mostly in Santo André, and they had a significant expansion (a growth of 282.6\%); however, they only occupied $5.1 \%$ of the Greenway. Three of the slums listed in this research are located in Santo André and one in Mauá, and one, the largest, the Vista Alegre slum, has parts in both cities. Although they experienced the greatest expansion in this preliminary survey, they accounted for just over $20 \%$ of the industrial areas. For this study, satellite imagery from Landsat 2005 and 2020 was used. Although the cities of the Greater $\mathrm{ABC}$ have more than 30 years' experience of slum urbanization practices (Larangeira, 2003; Moretti et al., 2015), it is important that this institutional knowledge evolve toward "green slum urbanization," focusing on green infrastructure, food production, and mitigation of climate change effects. Therefore, research on new and better upgraded models must be conducted to address the different local situations found in the Global South. Adegun (2017) discusses the potential for improving the quality of life and the environment through urban green infrastructure from the perspective of informal settlements; there are some examples of urban greening for lowincome settlements, including slum upgrades, in several cities in the Global South (Rocha, 2017, p. 248-254; Adegun, 2019; Caldas et al., 2021). These examples range from green roofs and community gardens and vivaria to the recovery of riparian corridors, slope reforestation, and other measures. Jerome (2017) argues that the development of green infrastructure at the community level presupposes the engagement of local groups that recognize its importance in addressing their pressing issues (e.g., ecological food systems).

Finally, the landfills and Espírito Santo dump site afford opportunities to expand the Greenway's vegetation and parks. The dump will be recovered and transformed into a small park of $\sim 1$ hectares. On the other hand, the landfill in Santo André will be closed in 5 or 6 years. Therefore, according to studies by the Solid Waste Department of Santo André (SEMASA, 2003), it may offer a park with an area of up to 15 hectares. In relation 
TABLE 2 | Summary table of opportunities and threats to the Greater ABC Greenway.

\begin{tabular}{|c|c|c|c|}
\hline Urban Elements & $\begin{array}{l}\text { Area } \\
\text { (hectares) }\end{array}$ & Opportunities & Threats \\
\hline Forest and Grassland & 545.02 & $\begin{array}{l}\text { Forest cover that occupies half of the forests of } \\
\text { Mauá, } 11 \% \text { of Ribeirão Pires and } 6.5 \% \text { of the } \\
\text { Santo André forests. The bird survey shows } \\
\text { more than } 300 \text { species close to the Santo } \\
\text { André landfill, some at risk of extinction. }\end{array}$ & $\begin{array}{l}\text { Between } 2005 \text { and } 2020 \text { this forest coverage } \\
\text { (1207, } 79 \text { hectares and grassland, } 70.62 \\
\text { hectares) decreased by } 12.52 \% \text {, mainly from } \\
\text { the expansion of the industrial park, urbanized } \\
\text { areas, highways (Rodoanel), and informal } \\
\text { settlements. }\end{array}$ \\
\hline Parks & 54.1 & $\begin{array}{l}\text { The expansion of park areas and forest cover } \\
\text { may be possible, with actions in areas along }\end{array}$ & $\begin{array}{l}\text { There are only two parks in the Greenway, } \\
\text { covering only } 4.4 \% \text { of the area. }\end{array}$ \\
\hline
\end{tabular}

Industrial District

284.97

Informal Settlements

70.05

Landfill and Dump site
157.37 municipal boundaries. An example is the small strip of riparian vegetation on both sides of the Itrapoã Stream, which could become a park. This requires action by Santo André and Mauá making it possible to increase the parks' area to about 15 hectares.

Most of the forests are in the Mauá industrial district areas. One paint factory is carrying out forest management in an area equivalent to $12.25 \%$ of all Greenway Forest.

There are many experimental projects in several cities in the Global South that use green infrastructure, often edible green infrastructure. Despite many reference experiences, the Greater $A B C$ region requires the development of this slum upgrading greening process.

After the closure of the Santo André landfill, scheduled in six years, a park of about 15 hectares can be created. The environmental licensing of the Santo André landfill expansions led to the reforestation of 3 hectares of Guaraciaba Park. There is also the Espírito Santo Dump, which will be recovered and can be transformed into a small park (1 hectares). With the Mauá waste-to-energy plant, the company will reforest 4.06 hectares. It would be important for this reforestation to take place in the Greenway area.
The second largest in extent, this land use showed a second major expansion between 2005 and 2020 (83.57\%). There is clear industrial construction and equipment expansion with forest suppression, such as in Mauá in 2018 (11.2 hectares).

Although informal settlements occupy a smaller area than landfills, industrial districts, and forests, they expanded the most between 2005 and 2020 (285.05\%). This expansion occurred in areas susceptible to landslides and floods, such as springs, stream banks, and slopes.

The landfill expansions and the construction of the Mauá waste-to-energy incineration plant in the PMNP buffer zone can generate serious impacts in environmentally sensitive areas. Although all dumps have been closed since the end of the twentieth century in Greater ABC, more studies are needed to locate smaller old dumps for proper recovery. to Mauá, its landfill has a longer useful life; however, observing the environmental licensing of the incineration system, the company will reforest 4.06 hectares. From a planning perspective, it would be an advantage to use this reforestation process to improve the Greenway forest cover due to: (1) locally mitigate the effect of air pollution, (2) help to consolidate the area as a Greenway, and (3) it would improve the ecological benefits and ecosystem services provided by the Greenway for the local population.

Thus, we propose guidelines for protecting forests and developing and implementing urban greening. For that to happen, we must promote new research and develop and evaluate experimental projects (Ahern, 2013) to usher in the paradigm change that we suggest in this study. Another example is the need for the adoption of agroforestry processes and edible green infrastructure (Russo et al., 2017) in the Greenway.
It is important to keep in mind Ahern (2007) four planning strategies to develop new approaches to green infrastructure planning: (a) protective, aiming to act on the borders of PMNP and the large forest fragments in Mauá; (b) defensive, especially concerning the buffer zones; (c) offensive, with the restoration of the Espírito Santo Street dump site (the COFAP dump site remediation process is underway) and the recovery of degraded areas close to the parks; and (d) opportunistic, by means of the implementation of edible green infrastructure in informal settlements and the planting of trees alongside roads and avenues. Studies of forest fragments with the science of landscape ecology are examples of the application of these strategies. Thus, in this paper, we hope to encourage more discussions about the possible benefits of the application of the Climate Change Action Plan of the Greater ABC and the management plans for PMNP. 


\section{CONCLUSIONS}

As discussed in this article, urban greenways have gained prominence among planning professionals and researchers as a way to promote urban greening and the ecological connectivity at a certain level of urban and non-urban forest fragments. When implemented in a context of heterogeneous urban land use, these greenways can provide multiple ecosystem services and functions. This heterogeneous land use runs from the PMNP to the northern region of the Itrapoã Stream in an old industrial dump site. It has many socio-environmental problems that can be mitigated by planning strategies for urban greenways. In this location, we indicate possible exits and environmental projects to restore the quality of water and soil, in addition to protecting the important areas covered by the Atlantic Forest in this region.

Our review showed some possible opportunities and benefits of consolidating an area that still has a large forest cover. The practical importance of urban greening processes in the southeastern metropolitan region of São Paulo is highlighted. The recommendations and discussion presented were based on previously institutional instruments (or municipal and regional plans) that indicate elements that are in tune with opportunities to expand green areas in three municipalities of the Greater ABC. In this manuscript we demonstrate the importance of structuring the urban and socio-ecological systems to contain anthropic expansion in the patterns of twentieth-century Latin American cities. Furthermore, this socio-ecological system structured in the proposed greenway could produce large amounts of ecosystem services essential for SPMR. In this sense, it is necessary that urban-environmental governance be strengthened regionally and that it act on several simultaneous socio-environmental fronts and across borders. The implementation of green infrastructure in informal settlements may support the evolution, through local parameters, of "slum upgrading" that will promote ecological and economic benefits for the region, in addition to expanding the total green coverage of the municipalities.

As demonstrated in the discussions, the political processes involved in promoting environmental justice (in the pursuit of equitable distribution of environmental goods) and mitigating

\section{REFERENCES}

Abessa, D., Famá, A., and Buruaem, L. (2019). The systematic dismantling of brazilian environmental laws risks losses on all fronts. Nat. Ecol. Evol. 3, 510-511. doi: 10.1038/s41559-019-0855-9

Adegun, O. B. (2017). Green infrastructure in relation to informal urban settlements. J. Architect. Urban. 41, 22-33. doi: 10.3846/20297955.2017.1296791

Adegun, O. B. (2019). Green infrastructure in informal unplanned settlements: the case of Kya Sands, Johannesburg. Int. J. Urban Sustain. Dev. 11, 68-80. doi: 10.1080/19463138.2019.1565412

Ahern, J. (2007). "Green infrastructure for cities: the spatial dimension," in Cities of the Future: Towards Integrated Sustainable Water and Landscape Management, eds V. Novotny and P. Brown (London: IWA Publishing), 267-283.

Ahern, J. (2013). Urban landscape sustainability and resilience: the promise and challenges of integrating ecology with urban planning and design. Landsc. Ecol. 28, 1203-1212. doi: 10.1007/s10980-012-9799-z the effects of climate change pose a challenge to environmental governance, especially in the Global South. The implementation of green infrastructure based on local needs has proven to be opportune, especially in metropolitan regions with high population density. It is a powerful tool for improving the quality of life, including the impoverished population. At the same time, it produces ecosystem services that benefit the general population of the municipality and, to a greater extent, the region.

We believe that this manuscript scientifically contributes to the study agenda on urban greenways, green infrastructure, and ecosystem-based adaptation, among other emerging concepts, in the Global South cities. In addition, it may sensitize and demonstrate to planners and decision makers involved in the Great $\mathrm{ABC}$ Consortium of the value of implementing green infrastructure solutions.

\section{AUTHOR CONTRIBUTIONS}

All authors listed have made a substantial, direct, and intellectual contribution to the work and approved it for publication.

\section{FUNDING}

The São Paulo Research Foundation (FAPESP) supported this study with the Processes 2018/06685-9 and 2019/05644-0, which are part of the Thematic Project MacroAmb Environmental Governance in São Paulo Macro Metropolis in a climate variability context (2015/03804-9).

\section{ACKNOWLEDGMENTS}

We extend our gratitude to the reviewers for their constructive comments and suggestions. We would like to thank the MSW Management Department of Santo André Sanitation Service (DRS/SEMASA) for information about Santo André Landfill and Guaraciaba Park, and Beatriz Dunder (The Environmental and Energy Institute of the University of São Paulo- IEE-USP) for her assistance with the mapping work.
Barros, L. H. (2017). “A paisagem requalificada: dos lixões aos parques urbanos," in Estratégias Para a Infraestrutura Verde, eds P. Pellegrino and N. B. de Moura (Barueri: Manole), 289-261.

Berland, A., Shiflett, S. A., Shuster, W. D., Garmestani, A. S., Goddard, H. C., Herrmann, D. L., et al. (2017). The role of trees in urban stormwater management. Landsc. Urban Plann. 162, 167-177. doi: 10.1016/j.landurbplan.2017.02.017

Bonzi, R. S. (2017). "Paisagem como infraestrutura," in Estratégias Para a Infraestrutura Verde, eds P. Pellegrino and N. B. de Moura (Barueri: Manole), 212-283.

Brasil (2000). Lei n. 9.985, de 18 de Julho de 2000. Regulamenta o art. 225, $\$ 10$, Incisos I, II, III e VII da Constituição Federal. Institui o Sistema Nacional de Unidades de Conservação da Natureza (SNUC) e dá outras providências.

Brito, C. F. (2014). Avaliação dos efeitos da construção do rodoanel na qualidade da água e sedimento da represa do parque pedroso. Santo André-SP. Estudo geoquímico de hidrocarbonetos policíclicos aromáticos (HPAs), metais 
e elementos traço com vistas ao abastecimento público [Tese de Doutorado]. Universidade de São Paulo, São Paulo, Brazil.

Caldas, E. L., Jayo, M., Martins, H. L., and Oliveira, W. B. (2021). Mil Viveiros Para São Paulo. Aprendendo com União de Vila Nova. São Paulo: Minha Cidade. Available online at: https://vitruvius.com.br/revistas/read/ minhacidade/21.248/8053

Carlucci, M. B., Marcilio-Silva, V., and Torezan, J. M. (2021). "The Southern Atlantic forest: use, degradation, and perspectives for conservation," in The Atlantic Forest: History, Biodiversity, Threats and Opportunities of the Mega-Diverse Forest, eds M. C. M. Marques and C. E. V. Grelle (Cham: Springer), 91-111. doi: 10.1007/978-3-030-55322-7_5

CETESB (2013). Áreas Contaminadas. Condomínio Residencial Barão de Mauá - Município de Mauá. Available online at: https://cetesb.sp.gov.br/ areas-contaminadas/2013/11/22/condominio-residencial-barao-de-mauamunicipio-de-maua (accessed July 21, 2018).

CETESB (2018). Inventário Estadual de Resíduos Sólidos Urbanos, 2019. São Paulo: Série Relatórios.

Chen, Y., Gu, W., Liu, T., Yuan, L., and Zeng, M. (2017). Increasing the use of urban greenways in developing countries: a case study on wutong greenway in Shenzhen, China. Int. J. Environ. Res. Publ. Health 14:6. doi: 10.3390/ijerph14060554

CIGABC and FESPSP (2016). Plano Regional de Gestão Integrado de Resíduos Sólidos do Grande ABC - Santo André-SP. Available online at: https:// consorcioabc.sp.gov.br/imagens/noticia/Plano\%20Regional\%20de\%20Gestao $\% 20$ Integrada\%20de\%20Residuos\%20Solidos\%20do\%20Grande\%20ABC_ completo\%20para\%20site.pdf (accessed February 12, 2021).

CIGABC and ICLEI (2016). Plano de Ação de Enfrentamento as Mudanças Climáticas do Grande ABC (2016). Available online at: https://consorcioabc. sp.gov.br/imagens/noticia/Plano\%20de\%20Acao\%20de\%20Enfrentamento \%20as\%20Mudancas\%20Climaticas\%20do\%20Grande\%20ABC.pdf (accessed February 12, 2021).

CIGABC and UFABC (2016). Diagnóstico Habitacional Regional do Grande $A B C$, Relatório Final - Santo André. Available online at: https://consorcioabc. sp.gov.br/imagens/noticia/Diagnostico\%20Habitacional\%20Regional\%20do \%20Grande\%20ABC_versao\%20final.pdf (accessed February 12, 2021).

COMUGESAN (2020). Memória da Reunião Ordinária, 02/2020. Available online at: http://www.semasa.sp.gov.br/wp-content/uploads/2020/09/Mem \%C3\%B3ria-02-25.08.2020-reuni\%C3\%A3o-virtual.pdf (accessed February $12,2021)$

CPEA (2019). Estudo de Impacto Ambiental e Relatório de Impacto Ambiental (EIA/RIMA) da Unidade de Recuperação Energética - URE Mauá, 2019. São Paulo. Available online at: https://cetesb.sp.gov.br/eiarima/eia/EIA_224_2019. pdf (accessed January 18, 2021).

Do, Y., Kim, J. K., Kim, G. Y., and Joo, G. J. (2014). Importance of closed landfills as green space in urbanized areas: ecological assessment using carabid beetles. Landsc. Ecol. Eng. 10, 277-284. doi: 10.1007/s11355-013-0223-x

Dobbs, C., Escobedo, F. J., Clerici, N., de la Barrera, F., Eleuterio, A. A., MacGregor-Fors, I., et al. (2019). Urban ecosystem Services in Latin America: mismatch between global concepts and regional realities? Urban Ecosyst. 22, 173-187. doi: 10.1007/s11252-018-0805-3

Dong, X., Guo, H., and Zeng, S. (2017). Enhancing future resilience in urban drainage system: green versus grey infrastructure. Water Res. 124, 280-289. doi: 10.1016/j.watres.2017.07.038

Dorst, H., van der Jagt, S., Raven, R., and Runhaar, H. (2019). Urban greening through Nature-Based Solutions - key characteristics of an emerging concept. Sustain. Cities Soc. 49, 1-8. doi: 10.1016/j.scs.2019.101620

Dowbor, L. (2018). A Era Do Capital Improdutivo: Por Que oito Famílias Tem Mais Riqueza do que a Metade da População do Mundo? São Paulo: Autonomia Literária.

Dramstad, W. E., Olson, J. D., and Forman, R. T. T. (1996). "Landscape ecology principles," in Landscape Architecture and Land-Use Planning. Harvard University Graduate School of Design. Washington: Island Press.

EMPLASA (2017). Atlas de Uso e Ocupação do Solo do Município de SANTO ANDRÉ. Empresa Paulista de Planejamento Metropolitano S/A (EMPLASA). Available online at: https://www.emplasa.sp.gov.br/RMSP (accessed December 12,2020 ).

Escobedo, F. J., Giannico, V., Jim, C. Y., Sanesi, G., and Lafortezza, R. (2019). Urban forests, ecosystem services, green infrastructure and nature-based solutions: nexus or evolving metaphors? Urban For. Urban Green. 37, 3-12. doi: 10.1016/j.ufug.2018.02.011

Ferreira, V. G. (2012). Viabilidade ambiental de traçados rodoviários: o caso do trecho sul do Rodoanel Mário Covas, São Paulo [Tese de Doutorado]. Universidade de São Paulo, São Carlos, Brazil.

FIESP (2018). Inscrição da Akzo Nobel no $13^{\circ}$ Prêmio FIESP de Conservação e Reuso de Água - Projeto: Água, Essência da Cor. Available online at: https://www.fiesp.com.br/arquivo-download/?id=254063 (accessed February $12,2021)$.

Freitas, A. P. (2011). Parque Natural do Pedroso: uma unidade de conservação em área urbana [Dissertação de mestrado]. Faculdade de Arquitetura e Urbanismo; Universidade de São Paulo, São Paulo, Brazil.

Frischenbruder, M. T. M., and Pellegrino, P. (2006). Using greenways to reclaim nature in Brazilian cities. Landsc. Urban Plann. 76, 67-78. doi: 10.1016/j.landurbplan.2004.09.043

Heynen, N., Perkins, H. A., and Roy, P. (2006). The political ecology of uneven urban green space: the impact of political economy on race and ethnicity in producing environmental inequality in Milwaukee. Urban Affairs Rev. 42, 3-25. doi: $10.1177 / 1078087406290729$

IBGE (2012). Manual Técnico da Vegetação Brasileira. Rio de Janeiro: Instituto Brasileiro de Geografia e Estatística-IBGE.

IBGE (2021). Censos de 1960 a 1980. Available online at: https://www.ibge.gov.br/ (accessed March 15, 2021).

Jerome, G. (2017). Defining community-scale green infrastructure. Landsc. Res. 42, 223-229. doi: 10.1080/01426397.2016.1229463

Kirpichtchikova, T. (2009). Phytoremédiation par Jardins Filtrants d’un sol pollué par des métaux lourds: Approche de la phytoremédiation dans des casiers végétalisés par des plantes de milieux humides et étude des mécanismes de remobilisation/immobilisation du zinc et du cuivre. [Doctoral dissertation]. Université Joseph-Fourier, Grenoble, France.

Klenosky, D. B., Snyder, S. A., Vogt, C. A., and Campbell, L. K. (2017). If We transform the landfill, will they come? predicting visitation to freshkills park in New York City. Landsc. Urban Plann. 167, 315-324. doi: 10.1016/j.landurbplan.2017.07.011

Larangeira, A. A. (2003). Case Study: Santo André Mais Igual Program; Interventions at Sacadura Cabral, Tamarutaca, Capuava e Quilombo II - Santo André - SP. Rio de Janeiro: IBAM/CAIXA. Available online at: https://mirror. unhabitat.org/files/2044_e_santoandre_ingles.pdf (accessed March 20, 2021).

Lira, P. K., Portela, R. C. Q., and Tambosi, L. R. (2021). "Land-cover changes and an uncertain future: will the Brazilian atlantic forest lose the chance to become a hopespot?," in The Atlantic Forest: History, Biodiversity, Threats and Opportunities of the Mega-Diverse Forest, eds M. C. M. Marques and C. E. V. Grelle (Cham: Springer), 233-252. doi: 10.1007/978-3-030-55322-7_11

Little, C. E. (1995). Greenways for America. Baltimore, MD: Johns Hopkins University Press.

Liu, Y., Fan, H., Wei, M., Yin, L., and Yan, J. (2017). From edible landscape to vital communities: clover nature school. community gardens in Shanghai. Landsc. Architect. Front. 5:72. doi: 10.15302/J-LAF-20170308

Marguti, B. O. (2013). Políticas Habitacionais e Acesso à Cidade no Município de Santo André/SP. v. $15 n .1$ (ANAIS DO XV ENANPUR / Sessões Temáticas, 2013). Available online at: http://www.anpur.org.br/ojs/index.php/ anaisenanpur/article/view/381/371 (accessed March 20, 2021).

Marini, R. M. (2015). America Latina, Dependencia y Globalización. Buenos Aires: CLACSO.

Marques, M. C. M., Trindade, W., Bohn, A., and Grelle, C. E. V. (2021). "The Atlantic forest: an introduction to the Megadiverse forest of South America," in The Atlantic Forest: History, Biodiversity, Threats and Opportunities of the MegaDiverse Forest, eds, M. C. M. Marques and C. E. V. Grelle (Cham: Springer), 233-252. doi: 10.1007/978-3-030-55322-7

Martinez, W. (2018). ABC Perde Área Verde de 12 Campos de Futebol; Desmate foi Autorizado Pela Cetesb. Metrô ABC. Available online at: https://www. metrojornal.com.br/foco/2018/07/30/abc-perde-area-verde-de-12- camposde-futebol-desmate-foi-autorizado-pela-cetesb.html> (accessed March 18, 2018).

Matsuura, L. (2006). Edifício Barão de Mauá. O Município terá de Retirar Moradores de Área Contaminada em Mauá. Available online at: https://www. conjur.com.br/2006-set-28/municipio_retirar_moradores_area_contaminada (accessed March 18, 2018). 
Mauá (2007). Lei $n^{\circ}$ 4153, de 26 De Março de 2007. Aprova o Plano Diretor do Município de Mauá.

Mauá (2016). Lei Ordinária $N^{\circ} 5167$ de 1 de Julho de 2016. Altera Dispositivos da lei Municipal $n^{\circ} 4.968$ de 01 de Julho de 2014, Que Dispõe Sobre o Uso, Ocupação e urbanização do Solo.

McPherson, E. G., and Muchnick, J. (2005). Effects of street tree shade on asphalt concrete pavement performance. J. Arboric. 31:30310. Available online at: https://www.fs.usda.gov/treesearch/pubs/46009 (accessed March 1, 2021).

Melo, A. (2020). Semasa Inicia Ampliação do Aterro Sanitário. Diário do Grande ABC. Available online at: https://www.dgabc.com.br/Noticia/3609455/semasainicia-ampliacao-do-aterro-sanitario (accessed March 3, 2021).

Momm-Schult, S. I., Freitas, S., and Passarelli, S. (2014). Uso urbano e serviços ecossistêmicos em áreas protegidas: o caso do Parque Guaraciaba em Santo André (SP). III Seminário Sobre Tratamento de Áreas de Preservação Permanente em Meio Urbano e Restrições Ambientais ao Parcelamento do Solo. APP Urbana. Beléml. Available online at: http://anpur.org.br/app-urbana2014/anais/ARQUIVOS/GT2-145-87-20140527172841.pdf (accessed March 3, 2021).

Moreno, R. S., Moraes, E. A., Consoni, A. J., and Lima, C. P. C. S. (2012). Banco de Áreas de Preservação Permanente para Compensação Ambiental no Município de Santo André-SP. XVI Exposição de Experiências Municipais em Saneamento. ASSEMAE (10 a 15 de junho de 2012). Maringá. Available online at: http:// trabalhosassemae.com.br/2012/PENDRIVE/pdf/VIII- 10.pdf (accessed May 13, 2020).

Moretti, R. S., Denaldi, R., Paiva, C. F. E., Nogueira, F. R., and Petrarolli, J. (2015). "Slum upgrading within the 'informal settlements urbanization - growth acceleration program (PAC-UAP)'. A case study of the ABC region within the Metropolitan Region of São Paulo," in RC21 International Conference on The Ideal City: Between Myth and Reality (Rome). Available online at: http://www. rc21.org/en/wp-content/uploads/2014/12/D4-Petrarolli-Moretti.pdf (accessed February 12, 2021).

Moura, N. C. B. (2017). The jaguaré creek revitalization project: transforming são paulo through a green stormwater infrastructure. Proc. Eng. 198, 894-906. doi: 10.1016/j.proeng.2017.07.165

Mucci, J. L. N., Souza, A., and Vieira, A. (2004). Estudo ecológico do Parque Guaraciaba em Santo André - São Paulo. Engenharia sanitária e ambiental. 9, 13-25.

Muylaert, R. L., Vancine, M. H., Bernardo, R., Oshima, J. E. F., Sobral-Souza, T., Tonetti, V. R., et al. (2018). Uma nota sobre os limites territoriais da mata atlântica - a note on the territorial limits of the Atlantic Forest. Oecol. Austr. 22, 302-311. doi: 10.4257/oeco.2018.2203.09

Nagendra, H., Bai, X., Brondizio, E. S., and Lwasa, S. (2018). The Urban south and the predicament of global sustainability. Nat. Sustain. 1, 341-349. doi: 10.1038/s41893-018-0101-5

Nagendran, R., Selvam, A., Joseph, K., and Chiemchaisri, C. (2006). Phytoremediation and rehabilitation of municipal solid waste landfills and dumpsites: a brief review. Waste Manage. 26, 1357-1369. doi: 10.1016/j.wasman.2006.05.003

Ogata, M. G. (1983). Os Resíduos Sólidos na Organização do Espaço e na Qualidade do Ambiente Urbano: Uma Contribuição Geográfica ao Estudo do Problema na Cidade de São Paulo. Rio de Janeiro: IBGE.

Okamura, C., Lolive, J., Romieu, P., Thibaud, J. P., and Tixier, N. (2015). Poética Do Condomínio Barão de Mauá. Como Restituir a Persistência Do Meio de Vida Em Uma Área Contaminada? Id: Halshs-02943484. Territorium, Universidade de Coimbra. doi: 10.14195/1647-7723_22_3

Pauchard, A., and Barbosa, O. (2013). "Regional assessment of Latin America: rapid urban development and social economic inequity threaten biodiversity hotspots," in Urbanization, Biodiversity and Ecosystem Services: Challenges and Opportunities, eds T. Elmqvist, M. Fragkias, J. Goodness, B. Güneralp, P. J. Marcotullio, R. I. McDonald, S. Parnell, M. Schewenius, M. Sendstad, K.C. Seto, and C. Wilkinson (Dordrecht: Springer), 589-608.

Pires, A. P. F., Shimamoto, C. Y., Padgurschi, M. C. G., Scarano, F. R., and Marques, M. C. M. (2021). "Atlantic forest: ecosystem services linking people and biodiversity," in the Atlantic Forest: History, Biodiversity, Threats and Opportunities of the Mega-Diverse Forest, eds M. C. M. Marques and C.E.V. Grelle (Cham: Springer), 233-252. doi: 10.1007/978-3-030-5532 2-7_16
Pírez, P. (2013). La urbanización y La política de los servicios urbanos en America Latina. Andamios 10, 45-67. doi: 10.29092/uacm.v10i22.266

Poletto, C. (2006). A exploração de pedreiras na região metropolitana de São Paulo no contexto do planejamento e gestão do território [Tese de Doutorado]. Universidade de São Paulo, São Paulo, Brazil.

Rafael, L. F. A. (2006). Resíduos sólidos e evolução urbana em Santo André-SP [Dissertação de mestrado]. Escola Politécnica da Universidade de São Paulo, São Paulo, Brazil.

Ribeiro, D. Jr. (2008). Desindustrialização do ABC: emprego e desemprego em tempos de mudança. [Dissertação de mestrado]. Faculdade de Ciências Administrativas da Universidade Metodista de São Paulo, São Bernardo do Campo, Brazil.

Ribeiro, R. R. (2015). Green belt biosphere reserve in the Brazilian city of São Paulo. Ecol. Quest. 20, 93-97. doi: 10.12775/EQ.2014.021

Rocha, H. F. M. (2017). O lugar das práticas comunitárias emergentes: caminhos de coexistência socioecológica em projetos urbanos [Tese de Doutorado]. Universidade Federal da Bahia, Salvador, Bahia.

Rodrigues, L. S., and Zanirato, S. H. (2021). Do lixão à moradia: uma análise das representações sociais de risco dos residentes do Conjunto Heliópolis - SP. Saúde e Meio Ambiente 10, 91-101. doi: 10.24302/sma.v10.3216

Russo, A., Escobedo, F. J., Cirella, G. T., and Zerbe, S. (2017). Edible green infrastructure: an approach and review of provisioning ecosystem services and disservices in urban environments. Agric. Ecosyst. Environ. 242, 53-66. doi: 10.1016/j.agee.2017.03.026

Santo André (2004). Lei municipal $n^{\circ} 8696$ de 17 de dezembro de 2004. Institui o novo Plano Diretor do município de Santo André.

Santo André (2006). Plano Municipal de Habitação. Santo André: Prefeitura de Santo André.

São Paulo (2009). Lei Estadual n. 13.579, de Dezembro de 2009. Define a Área de Proteção e Recuperação dos Mananciais da Bacia Hidrográfica da Billings e dá Outras Providencias Correlatas. Available online at: http://www.jusbrasil.com. br/legislacao/818001/lei-13579-09-sao-paulo-sp (accessed March 19, 2021).

São Paulo (2019). Ata da Audiência Pública Sobre o EIA-RIMA do Empreendimento 'Unidade de Recuperação Energética - URE /Mauá', de Responsabilidade da Lara Central de Tratamento de Resíduos Ltda., realizada em 12 de dezembro de 2019, no município de Mauá/SP. Available online at: https://smastr16.blob.core. windows.net/consema/sites/15/2020/06/ata_ap_unidade-de-recuperacaoenergetica-ure-lara-central-de-tratamento-de-residuos-ltda_maua_12.12. 2019.pdf (accessed March 21, 2021).

São Paulo (2020). Secretaria de Infraestrutura e Meio Ambiente. Inventário Florestal 2020. Available online at: https://www.infraestruturameioambiente.sp.gov.br/ tag/inventario-florestal-2020/ (accessed March 21, 2021).

SEADE (2021). Fundação Sistema Estadual de Análise de Dados. Perfil dos Municípios Paulistas. Available online at: https://perfil.seade.gov.br/ (accessed February 10, 2021).

SEMASA (2003). Relatório sobre o Macrozoneamento $e$ as Diretrizes de Uso e Paisagismo, para o Projeto de Prosseguimento do Aterro Sanitário de Santo André.

SEMASA (2004). Plano de Recuperação de Áreas Degradadas - PRAD - Parque do Guaraciaba. Volumes I e II, Revisão 1.

SEMASA (2008). Estudo de Impacto Ambiental da Ampliação da Central de Tratamento de Resíduos/ Aterro Sanitário de Santo André.

SEMASA (2011). Diretiva Recuperação de Mata Ciliar do Programa Município Verde e Azul, Relatório Descritivo.

SEMASA (2016). Plano de Manejo do Parque Natural Municipal do Pedroso. Santo André. Available online at: http://www.semasa.sp.gov.br/wp-content/uploads/ 2014/08/Plano-de-Manejo-Pedroso_Diagnostico_Dez-2016-altElenadestacado-5.pdf (accessed November 12, 2020).

SEMASA (2021). Resitec. Aterro Sanitário Municipal de Santo André - PMSA SEMASA. Relatório Referente ao Monitoramento de Fauna: Jacuaçu - Penelope obscura (Temminck 1815).

Serra-Llobet, A., and Hermida, M. A. (2017). Opportunities for green infrastructure under ecuador's new legal framework. Landsc. Urban Plann. 159, 1-4. doi: 10.1016/j.landurbplan.2016.02.004

Swyngedouw, E., Kaika, M., and Castro, J. E. (2002). Urban water: a politicalecological perspective. Built Environ. 28, 124-137. doi: $10.2307 / 23288796$

Thomaier, S., Specht, K., Henckel, D., Dierich, A., Siebert, R., Freisinger, U. B., et al. (2015). Farming in and on urban buildings: present practice and specific 
novelties of Zero-Acreage Farming (ZFarming). Renew. Agric. Food Syst. 30, 43-54. doi: 10.1017/S1742170514000143

Travassos, L., Torres, P. H. C., Di Giulio, G., Jacobi, P. R., Freitas, E. D., Siqueira, I. C., et al. (2021). Why do extreme events still kill in the são paulo macro metropolis region? Chronicle of a death foretold in the global south. Int. J. Urban Sustain. Dev. 13, 1-16. doi: 10.1080/19463138.2020.1762197

Tzoulas, K., Korpela, K., Venn, S., Yli-Pelkonen, V., Kazmierczak, A., Niemela, J., et al. (2007). Promoting ecosystem and human health in urban areas using green infrastructure: a literature review. Landsc. Urban Plann. 81, 167-178. doi: 10.1016/j.landurbplan.2007.02.001

UNESCO (2021). São Paulo Green Belt Biosphere Reserve, Brazil. Available online at: https://en.unesco.org/biosphere/lac/saopaulo-greenbelt (accessed March 21, 2021).

Vásquez, A., Giannotti, E., Galdámez, E., Velásquez, P., and Devoto, C. (2019). "Green infrastructure planning to tackle climate change in latin american cities," in Urban Climates in Latin America, eds C. Henríquez and H. Romero (Cham: Springer), 329-354. doi: 10.1007/978-3-319-97013-4_13

$\mathrm{Yu}, \mathrm{K}$. , and Padua, M. (eds.). (2006). The Art of Survival: Recovering Landscape Architecture. Mulgrave, VIC: Images Publishing Group Pty Ltd.
Conflict of Interest: The authors declare that the research was conducted in the absence of any commercial or financial relationships that could be construed as a potential conflict of interest.

Publisher's Note: All claims expressed in this article are solely those of the authors and do not necessarily represent those of their affiliated organizations, or those of the publisher, the editors and the reviewers. Any product that may be evaluated in this article, or claim that may be made by its manufacturer, is not guaranteed or endorsed by the publisher.

Copyright (C) 2021 Moreno, Braga and Xavier. This is an open-access article distributed under the terms of the Creative Commons Attribution License (CC BY). The use, distribution or reproduction in other forums is permitted, provided the original author(s) and the copyright owner(s) are credited and that the original publication in this journal is cited, in accordance with accepted academic practice. No use, distribution or reproduction is permitted which does not comply with these terms. 